YAK $347.45 / .47$

DOI https://doi.org/10.32837/chc.v0i38.368

\author{
Войчишин Олексій Валентинович, \\ аспірант \\ Навчально-наукового інституту права імені Іоаннікія Малиновського \\ Національного університету "Острозька академія" \\ ORCID https://orcid.org/0000-0003-0612-1383
}

\title{
ЩОДО ІСТОТНИХ УМОВ КОРПОРАТИВНОГО ДОГОВОРУ В ТОВАРИСТВАХ 3 ОБМЕЖЕНОЮ ВІДПОВІДАЛЬНІСТЮ
}

Корпоративний Аоговір лише нещодавно був закріплений у законодавстві України із прийняттям у 2018 році Закону України «Про товариства з обмеженою та Аодатковою відповідальністю" (надалі - "Закон про ТОВ"). Саме "новизна" цієї юриАичної конструкції зумовлює піАвищений інтерес як зі сторони професійних юристів, так і зі сторони пересічних громаАян, особливо тих, що займаються піАприємницькою Аіяльністю. Як правило, АосліАження Аоговорів розпочинається саме із вивчення їх істотних умов як ключового елементу Аоговірної конструкції. Без розуміння істотних умов Аоговору неможливо виокремити його специфіку, віАмежувати Аоговір віА інших Аоговорів, розкрити природу Аоговору.

Важливість істотних умов полягає ще й у тому, що в разі віАСУтНОсті ЗГОАИ ЩОАО всіХ істОтних умов, такий договір вважатиметься неукладеним. Як насліАок, у разі віАсутності Аосконалого розуміння істотних умов Аоговору завжди залишатимуться очевиАні ризики Аля сторін, які уклаАають такий договір. Саме тому дане питання потребує детального та комплексного аналізу.

Ао питання істотних умов корпоративного Аоговору у своїх АосліАженнях звертались М.М. СигиАин, Н.В. Щербакова, С.О. Сліпченко, В.І. Цікало, М.О. Суханов. Варто віАмітити, що питання умов корпоративного Аоговору продовжує залишатися преАметом активної дискусії сереА науковців в силу данамічного розвитку законодавства у Ааній сфері та віАсутності усталеної практики.

Метою цієї статті $€$ визначення істотних умов корпоративного Аоговору та їх обгрунтування.

Цивільний кодекс України визначає, що будь який договір є укладеним лише тоді, коли сторони
Аосягли ЗгоАИ з усіх істотних Умов Аоговору [10]. Іншими словами, істотними умовами вважаються ті положення договору без яких договір не може вважатися Аоговором та не може породжувати юриАичних прав та обов'язків Аля його сторін.

Стаття 638 Цивільного кодексу України Ао істотних умов Аоговору відносить:

1) умови про предмет Аоговору;

2)умови, що визначені законом як істотні або умови, що $€$ необхідними Аля Аоговорів Ааного виАу;

3) а також усі ті умови, щодо яких за заявою хоча б оАнієї із сторін має бути Аосягнуто згоАи [10].

Першою істотною умовою, яку визначає ЦКу $€$ преАмет Аоговору. ПреАмет корпоративного Аоговору визначений у ч. 1 ст. 7 Закону про ТОВ. Зокрема, предметом корпоративного Аоговору $€$ реалізація учасниками товариств з обмеженою віАповіАальністю (наАалі - "ТОВ") своїх права та повноваження певним чином або утримання віА їх реалізації [5]. 3 цієї норм випливає, що не просто права та повноваження $\epsilon$ істотною умовою, а саме порядок або спосіб їх реалізації учасниками повинні бути визначені у корпоративному Аоговорі та $€$ істотними умовами. 3 цього у сукупності із ч. 2 ст. 6 Закону про ТОВ сліаує і протилежне, що корпоративний договір не може створювати нових корпоративних прав сторін як учасників Товариства або припиняти вже наявні корпоративні права.

Господарський кодекс України визначає, що корпоративні права - це права особи, частка якої визначається у статутному капіталі (майні) господарської організації, що включають правомочності на участь цієї особи в управлінні госпо- 
Аарською організацією, отримання певної частки прибутку (Аивідендів) Ааної організації та активів у разі міквідації останньої віАповідно до закону, а також інші правомочності, передбачені законом та статутними документами [2]. Отже, права учасників ТОВ визначаються виключно у статуті та/або законі.

Наведемо практичні ситуації, кожен учасник товариства з обмеженою відповідальністю має право голосу на загальних зборах. Корпоративний договір не може позбавити учасника права голосу, однак учасник у корпоративному Аоговорі може погодитись голосувати або не голосувати певним чином. НаприклаА, протягом 3 років не голосувати за зміни до статуту товариства.

В іншій ситуації учасники товариства бажають передбачити право учасників на отримання в користування в позачерговому поряаку послуг, які надає їх товариство. Оскільки таке право учасників прямо не передбачено в законодавстві України, воно повинне бути зафіксоване саме у статуті, а не у корпоративному Аоговорі, в силу ч. 2, ст. 5 Закону про ТОВ. У цьому випадку в корпоративному договорі можна лише передбачити порядок реалізації такого права, наприклад черговість отримання учасниками послуг їх товариства.

ЄАиний випаАок, коли Аоговір може припинити корпоративне права учасника, прямо визначений у ч. 9 ст. 20 Закону про ТОВ: переважне право учасника ТОВ не застосовується у разі, якщо це передбачено корпоративним Аоговором. Варто наголосити, що в цій статті говориться виключно про припинення корпоративного права учасника. ОАнак комплексний аналіз законодавства Аозволяє стверАжувати, що це єАиний виняток, який прямо передбачений спеціальним законом.

СереА науковців такої ж позиції дотримуються В. Цікало та М. СигиАин. На Аумку В. Цікало, зобов'язання сторін не мають самостійного характеру та не можуть вважатися предметом корпоративного Аоговору. К^ючовим $€$ те, що сторони за таким Аоговором визначають, насампереА, поряАок реалізації прав належних їм як учасникам TOB [11]. На цьому акцентують увагу й автори Закону про ТОВ, а саме: «У законі і статуті можуть бути встановлені певні повноваження учасників, а у корпоративному Аоговорі - зобов'язання сторін про їх реалізацію певним чином" [4].

М. Сигидин вважає, що предметом у корпоративному Аоговорі виступають не самі корпоративні права, а сукупність спільних взаємоузгоджених Аій учасників юридичної особи корпоративного типу [7, с. 197]. Ми цілком піА- тримуємо науковця, оскільки саме порядок або спосіб реалізації корпоративних прав існує якраз у формі певних взаємоузгоАжених Аій.

3 огляду на те, що питання преАмету корпоративного Аоговору $€$ Ауже Аискусійним сереА науковців, Аеякі вчені, такі як Н. Щербакова, С. Сліпченко, мають Аещо інші погляди на преАмет корпоративного Аоговору.

НаприклаА, С. Сліпченко відносить до предмету корпоративного Аоговору "корпоративні правовіАносини, зміст яких становлять корпоративні права та обов'язки" [8, с. 43]. По-перше, варто відмітити, що своє АосліАження науковець провоАила ще Ао прийняття українським парламентом Закону про ТОВ і Ао проведення реформи корпоративних договорів, що мала місце у 2017 році. По-Аруге, на нашу Аумку, така позиція є мише частково правильною. Безумовно, корпоративні права та обов'язки входять Ао преАмету корпоративного договору, оскільки саме Аля визначення порядку реалізації корпоративних прав і обов'язків корпоративний договір і укладається. ОАнак корпоративні права та обов'язки не є самостійним предметом, оскільки це означало би, що вони можуть виникати, змінюватися та припинятися в корпоративному Аоговорі. А як ми вже з'ясували, такого юридично в корпоративному Аоговорі не відбувається.

Н.В. Щербакова вважає, що розуміння способу реалізації прав учасників в якості самостійного преАмету корпоративного Аоговору $є$ обмеженим. Авторка акцентує увагу на розмежуванні предмету корпоративного Аоговору та предмету закону і статуту [13]. ОАнак, на нашу Аумку, це мише Аодатковий аргумент на піАтримку того, що корпоративні права та обов'язки не $є$ самостійним предметом корпоративного Аоговору. Оскільки права та обов'язки учасників ТОВ визначаються виключно у статуті та/або законі (ст. 6 Закону про ТОВ). Вищезазначене розмежування лише підкреслює неможливість включення Ао самостійного преАмету корпоративного Аоговору корпоративних прав. Крім того, на необхіАності розмежування предмету статуту та закону віА преАмету корпоративного Аоговору наголошують й автори Закону про ТОВ [4].

Також варто віАмітити й значну Аиспозитивність, яка закладена у формулювання предмету корпоративного договору Законом про ТОВ. На цьому наголошує й Ю. Попов, який зазначає, що ч. 1 ст. 7 Закону про ТОВ "використовує норму високого ступеня абстрактності, щоб піА гіпотезу норми попадали найрізноманітніші ситуації 
та навіть забаганки учасників" [3]. Таке рішення безумовно $є$ позитивним кроком з точки зору практики, однак Аещо усклаАнює визначення істотних умов.

Аеякі приклади того, порядок реалізації яких прав може бути предметом корпоративного Аоговору $є$ в самому Законі про ТОВ. Так, це може бути право відчужувати або придбавати частку у статутному капіталі Товариства (ч. 3 ст. 7 Закону про ТОВ) [5]. Щодо права відчужувати або приАбавати частку, у корпоративному Аоговорі визначається випаАки обов'язкового продажу або обов'язкового викупу частки, порядок визначення ціни частки, порядок укладення Аоговору купівлі-продажу частки або навіть деякі умови такого договору.

Ао Аругої категорії істотних умов - умови, які $\epsilon$ істотними в силу або характерними Ая Аоговорів Ааного виАу, сліА, на нашу Аумку, віАнести строк корпоративного Аоговору та його безоплатність.

Ч. 2 ст. 7 Закону про ТОВ встановлює, що в корпоративному Аоговорі повинні бути визначені дата укладення договору та його строк. Таким чином, будь-який корпоративний Аоговір повинен містити віАомості щодо часу, протягом якого сторони можуть зАійснити свої права і виконати свої обов'язки віАповіАно Ао Аоговору. Із цього сліАує, що корпоративний Аоговір можуть уклаАати:

1) на конкретно визначений період часу наприклаА, Ава роки (абсолютне визначення);

2) на весь час Аіяльності ТОВ (Ао моменту Аержавної реєстрації припинення);

3) до Аосягнення певної мети, якщо така мета передбачена Аоговором;

4) Ао виникнення ситуації, коли 100\% статутного капіталу ТОВ належатиме оАному учаснику;

5) до моменту його припинення за взаємною згодою сторін.

Ст. 7 Закону про ТОВ прямо встановлює, що корпоративний Аоговір є безоплатним. Крім того, також зазначається, що недотримання умови про безоплатність тягне за собою нікчемність такого Аоговору. 3 огляду на це вважаємо, що безоплатність $€$ також істотною умовою корпоративного Аоговору. У разі якщо сторони не можуть Аійти згоди щодо безоплатності корпоративного Аоговору, то такий Аоговір недійсний в силу закону.

Як зазначали автори Закону про ТОВ, вк^ючення умови про безоплатність Аоговору пересліАувало мету зменшити ризики захоплення контролю наА товариством та змови окремих груп учасників проти інших [4]. Як вбачається, віАсутністю оплатності автори намагалися нівелювати вплив учасників, які володіють значними фінансовими ресурсами, та створити умови Аля більшої рівноправності сторін.

Умови, щоАО яКих за заявою Хоча б оАнієї із сторін має бути Аосягнуто згоАи. Цю категорію істотних умов ще називають "суб'єктивно істотними", оскільки вони на пряму залежать віА волі сторін. А^я того щоб вважати умову суб'єктивно істотною необхіАно, щоб одна із сторін корпоративного Аоговору прямо підкреслила необхінність включення такої умови до Аоговору, інакше така сторона віАмовиться віА укладення Аоговору [1, с. 44].

Фундаментальним Аля цієї категорії істотних умов є принцип свобоАи Аоговору - сторони вільні у виборі умов Аоговору. Тому істотні умови цієї категорії можуть мати дуже різний характер, що залежить виключно віА волі сторін.

Варто наголосити, що, незважаючи на свободу Аоговору в Аоговірному праві, така свобода все ж не $є$ абсолютною. У першу чергу, мається на увазі, що умови, на яких піА загрозою віАмови віА укладення Аоговору наполягає одна із сторін, не повинні суперечити законодавству. НаприклаА, ч. 3. ст. 7 Закону про ТОВ забороняється встановлювати в корпоративному Аоговорі обов'язок учасників забезпечити голосування згідно із вказівками органів управління ТОВ. У разі наявності таких положень у корпоративному Аоговорів такий Аоговір є нікчемним. На Аумку М.О. Суханов, така норма призначена Аля усунення будь-яких маніпуляцій у процесі управління товариства та гарантування рівних умов участі учасників в управлінні TOB. Водночас науковець акцентує увагу на тому, що норма не є досконалою, оскільки передбачає заборону лише щодо голосування за вказівками органів управління, однак не говорить про інші органи та/або особи [9].

По-Аруге, принцип свободи Аоговору А^я сторін корпоративного Аоговору обмежується ще оАним фактором - статутом. Тому умови, на яких напо^ягають сторони, не повинні суперечити статуту.

Як бачимо, вичерпну віАповіАь на питання щодо істотних умов корпоративного Аоговору могла би Аати судова практика як критерій істини. ВіАповіАно Ао віАомостей з ЄАиного Аержавного реєстру судових рішень судова практика щодо корпоративних Аоговорів мише починає формуватися судами України.

НаприклаА, справа № 916/1444/19 стала першою справою, у якій було винесено рішення щодо корпоративних Аоговорів в контексті Закону про ТОВ. ОАнак у справі № 916/1444/19 спір стосувався положень корпоративного Аоговору 
щодо переходу права власності на частки та зберіганні установчих документів, а істотні умови не виступали преАметом розгляАу [6].

Висновки. Можемо стверАжувати, що Аля корпоративного Аоговору передбачено три істотні умови: преАмет Аоговору, безоплатність та строк Аоговору. У зв'язку зі значною Аиспозитивністю, яка закладена Законом про ТОВ в аспекті регу^ювання корпоративних Аоговорів, та відсутністю сформованої судової практики щодо корпоративних Аоговорів найбільш Аискусійним залишається питання про преАмет корпоративного договору.
Ми вважаємо, що предмет корпоративного Аоговору становить порядок реалізації учасниками ТОВ своїх корпоративних прав та обов'язків. "Суб'єктивно істотні" умови корпоративного Аоговору, які мають свою специфіку та межі.

Перспективи подальших АосліАжень. У майбутньому Аоцільним вбачаються такі напрями Аосліджень: Аослідження істотних умов Аоговору між акціонерами в акціонерних товариствах та порівняння українського законодавства в цьому напрямку 3 найкращими світовими практиками.

\section{AITEPATYPA:}

1. Блащук Т.В. Умови договору, щодо яких за заявою хоча б однієї із сторін має бути досягнуто згоди. Теорія $i$ практика застосування чинного вітчизняного та міжнародного законодавства в сучасних умовах: матеріали наук.-практ. конф. Одеса, 2011. Ч. 2. С. $43-45$.

2. Господарський кодекс України від 16.01.2003 № 436-IV / Верховна Рада України. URL : https://zakon.rada.gov.ua/laws/ show/436-15/ed20200402\#Text (дата звернення: 19.06.2020).

3. Попов Ю. Корпоративні договори: подальший розвиток у Законі «Про товариства з обмеженою та додатковою відповідальністю». Юридична Газета. 2018. № 10. URL : https://yur-gazeta.com/publications/ practice/korporativne-pravo-ma/korporativnidogovori.html (дата звернення: 13.06.2020).

4. Пояснювальна записка до проекту Закону України «Про товариства з обмеженою та додатковою відповідальністю» від 13.05.2016. URL : http://w1.c1.rada.gov.ua/pls/zweb2/webproc34?id=\&pf3511=59093\&pf35401=387857 (дата звернення: 19.06.2020).

5. Про товариства з обмеженою та додатковою відповідальністю: Закон України від 06.02.2018 р. № 2275-VIII / Верховна Рада України. URL : https://zakon.rada.gov.ua/laws/show/2275-19 (дата звернення: 13.06.2020).

6. Рішення Господарського суду Одеської області у справі № 916/1444/19 від 28.11.2019 року. URL : http://www.reyestr.court.gov.ua/Review/86175401 (дата звернення: 10.06.2020).

7. Сигидин М. М. Відмежування корпоративного договору від інших суміжних договірних конструкцій. Часопис Київського університету права. 2016. № 1. С. 195-199.

8. Сліпченко С.О. Деякі питання визначення предмета корпоративних правочинів. Корпоративні правочини: матеріали Всеукраїнської наук.-практ. конф, 27-28 вересня 2013 року. Івано-Франківськ : 2013. С. 41-45.

9. Суханов М.О. Сутність і зміст корпоративного договору як підстави набуття корпоративних прав та обов’язків учасника товариства 3 обмеженою відповідальністю. Прикарпатський Юридичний Вісник. № 1(26). С. 70-73. URL : http://pyuv.onua.edu.ua/index.php/pyuv/article /view/14/14 (дата звернення: 19.06.2020).

10. Цивільний кодекс України від 16.01.2003 № 435-IV / Верховна Рада України. URL : https://zakon.rada.gov.ua/laws/show/43515 (дата звернення: 13.06.2020).

11. Цікало В. Предмет договору про здійснення прав учасників господарського товариства. Підприємництво, господарство $i$ право. 2017. № 2. C. 68-73. URL : http://nbuv.gov.ua/UJRN/Pgip_2017_2_14 (дата звернення: 10.06.2020).

12. Щербакова Н.В. Питання змісту корпоративного договору. Міжснародний журнал «Право і суспільство». 2018. № 8. C. 123-132. URL : https://journals.pnu.edu.ua/index.php/LS/article/download/301/325 (дата звернення: 13.06.2020).

\section{Войчишин Олексій Ваментинович}

ЩОАОІСТОТНИХУМОВ КОРПОРАТИВНОГОАОГОВОРУВТОВАРИСТВАХЗОБМЕЖЕНОЮВІАПОВІАААЬНІСТЮ

Поняття "корпоративного Аоговору" Аля товариства з обмеженою віАповіАальністю є новелою вітчизняного законодавства, оскільки було закріплено лише два року тому. Як насліАок, дане правове явище все ще $є$ недостатньо АосліАженим та потребує формування усталених піАходів до його розуміння. У статті розглянуто істотні умови корпоративного Аоговору як ключовий елемент Аоговірної конструкції даного Аоговору. Визначено стан Аослідження проблематики та проаналізовано праці вчених з даного питання.

Базуючись на наукових розробках науковців, практиці укладення корпоративних договорів в Україні та наявній судовій практиці, зАійснено комплексний аналіз істотних умов корпоративного договору. Зокрема, проаналізовано преАмет корпоративного договору як істотну умови корпоративного Аоговору, умови, що визначені законом як істотні або умови, що $є$ необхідними Аля корпоративного договору; умови, щодо яких за заявою хоча б однієї із сторін має бути досягнуто згоди. За результатами аналізу детально обґрунтовано особливі межі предмету корпоративного договору - порядок реалізації учасниками своїх прав та обов'язків. Обґрунтовано, що корпоративні права та обов'язки не є самостійним предметом корпоративного договору, оскільки це означало би, що вони можуть виникати, змінюватися та припинятися у корпоративному Аоговорі. Саме тому в досліАженні наголошується на необхідності віАмежування предмету корпоративного Аоговору віА преАмету статуту та предмету Закону України «Про товариства з обмеженою та додатковою відповідальністю". Крім того, не можна не зазна- 
чити значну Аиспозитивність предмету корпоративного Аоговору, яка закладена авторами профільного закону.

Ао умов, що визначені законом як істотні, або умови, що $€$ необхіАними Аля корпоративного Аоговору, віАнесено безоплатність та строковість. Встановлено межі "суб'єктивно істотних" умов корпоративного договору, а саме: зафіксовано, що умови, на яких наполягає одна із сторін, не повинні суперечити статуту та законодавству України. Окрема увага зупинена на особливостях нікчемності корпоративного договору.

ЗАійснено аналіз та оцінку стану судової практики щодо корпоративних договорів. Виявлено, що судова практика щодо корпоративних договорів кише перебуває на стадії формування, підтвердженням чого є ^ише одне рішення в ЄАиному державному реєстрі судових рішень.

Киючові слова: корпоративний договір, товариства з обмеженою віАповідальністю, корпоративні права, статут, істотні умови договору, корпоративне право.

\section{Voichyshyn Oleksii}

REGARDING THE ESSENTIAL TERMS OF THE SHAREHOLDERS`AGREEMENTS FOR LIMITED LIABILITY COMPANIES

The concept of "shareholders' agreement" for a limited liability company is a novelty of national legislation since it was introduced only two years ago. Consequently, this legal institution is still insufficiently studied and requires the formation of single approaches to its understanding. The article considers the essential terms of a shareholders' agreement as a key element of contractual structure. The state of research of the problem is determined, and scientists' works on this issue are analyzed.

Based on other scientists' researches, the practice of concluding shareholders' agreement in Ukraine, and the existing court's practice, the essential terms of the shareholders' agreement have been analyzed. In particular, the subject of the shareholders' agreement as an essential condition of the agreement is studied, as well as conditions defined by law as essential or the conditions necessary for the shareholders' agreement and conditions on which, at the request of at least one of the parties, agreement must be reached. According to the analysis results, the individual limits of the subject of the shareholders' agreement are substantiated in detail - the order of realization participant's rights and obligations. It is justified that corporate rights and obligations are not an independent subject of the shareholders' agreement, as this would mean that they may arise, change, and terminate in the shareholders' agreement. Consequently, the study emphasizes the need to separate the subject of the shareholders' agreement from the subject of the charter and the subject of the Law of Ukraine "On Limited and Additional Liability Companies". In addition, it is necessary to note the significant dispositive nature of the subject of the shareholders' agreement.

The terms defined by law as essential or the terms necessary for a shareholders' agreement include gratuitousness and timeliness. The limits of the "subjectively essential' terms of the shareholders' agreement are established, namely: it is fixed that the terms on which one of the parties insists should not contradict the charter and the legislation of Ukraine. The peculiarities of the nullity of the shareholders' agreements have been considered.

The analysis and assessment of the court's practice on shareholders' agreements have been made. Since the Unified State Register of Court Decisions consists of only one decision on shareholders' agreements, it may be stated that the court 's practice on shareholders' agreements is only in the process of formation.

Key words: shareholders' agreement, limited liability company, corporate rights, charter, essential terms of the agreement, corporate law. 